\title{
BRACEROS AND GUESTWORKERS \\ IN THE UNITED STATES AND SPAIN: \\ A POLITICAL AND CONTEXTUAL ANALYSIS OF DIFFERENCE
}

\author{
Kitty CaLAVITA \\ University of California, Irvine
}

\section{Introduction}

The title of this conference- "Ejercicios de Diferencia"-refers to the twin experiences of multiculturalism and marginalization that occur as immigration brings increasing cultural diversity and economic segregation. In this paper I will examine these processes of diversity and segregation, but I will focus particular attention on the "diferencia" between the U.S. and Spain as these processes of difference are played out. Specifically, I will investigate the dramatically different socio-political construction of guestworker programs in these two countries, and the myriad lessons we can learn from this particular difference.

Foreign worker programs are a central ingredient of Spanish immigration policy, just as the Bracero Program for more than twenty years was a primary mechanism by which Mexican workers gained legal entry to the United States. The old Bracero Program and the Spanish foreign worker programs have much in common, but there is one area in which they diverge sharply. While the Bracero Program is associated with «slave labor» and "indentured servitude" and was vehemently opposed by organized labor and immigrant advocates (who are now organizing against attempts to revive the program), in Spain quota worker programs are considered the most progressive aspect of immigration policy, and it is organized labor, not employers, who push for program expansions.

In order to unravel this paradox, I will trace the history of the Bracero Program and briefly sketch recent efforts by growers to revive it; outline the distinctive immigration systems that provide a backdrop for these programs in the 
U.S. and in Spain; and, discuss the greater power of Spanish organized labor to shape economic relations. In concluding, I will suggest that this case study has significant ramifications for cross-cultural research, for public policy, and for progressive social action.

\section{The Bracero Program: Then and Now}

On September 29, 1942, five hundred farmworkers from Mexico arrived in Stockton, California. Transported by the U.S. government and delivered to California growers, these Mexican farmworkers were the first installment of a wartime emergency program designed to fill the declared labor shortage in agriculture. Over the next twenty-two years, five million "braceros" were contracted to growers and ranchers in twenty-four states.

For much of the twentieth century, growers and ranchers in the southwestern United States had relied on a plentiful supply of undocumented Mexican workers. In recognition of the economic benefits of this virtually limitless supply, the Immigration Service often followed an informal policy of non-enforcement. The Chief Inspector at Tucson, Arizona, for example, reported that he ureceived orders from the District Director at El Paso each harvest to stop deporting illegal Mexican labor» (Kirstein, 1977: 90). During World War II, the INS District Director in Los Angeles explained that it was his policy not to check farms and ranches for undocumented workers during the harvest (Calavita, 1992: 33). In 1949, the Idaho State Employment Service reported, «The United States Immigration and Naturalization Service recognizes the need for farm workers in Idaho and... withholds its search and deportation until such times as there is not a shortage of farm workers" (quoted in President's Commission on Migratory Labor, 1951: 76). The implicit message from Congress during this period was consistent with this laissez-faire approach. As one observer put it in the early 1950s, Congress was «splendidly indifferent" to the rising number of illegal immigrants (Hadley, 1956: 334). So lax was enforcement and so pervasive the notion that undocumented Mexican immigrants were an integral component of southwestern agriculture that increased border control was often seen by U.S. policymakers as a Mexican government demand (U.S. Congress. House Committee on Agriculture, 1947: 36).

In the 1950s, INS Commissioner-General Swing launched "Operation Wetback," consisting of the massive deportation of undocumented, and some docu- 
mented, Mexican workers and their families. At first alarmed by the aggressive new policies of the INS, growers soon learned that the infusion of Braceros that Swing provided them with-in what he called an «exchange» (U.S. Immigration and Naturalization Service 1954: 9)—had decided advantages.

To understand these advantages, it helps to consider the production process in agriculture. Pfeffer (1980:25) describes this process, including its seasonal nature and the urgency of harvest, and concludes, "The characteristics of the labor process in crop production place constraints on the forms of control growers must exert over workers for profitable completion of the harvest.m While undocumented Mexican workers had for years provided growers with the surplus workforce with which to enhance the profitability of agricultural production, the contract system was unusually suited to the exercise of control.

A cotton farmer told the President's Commission on Migratory Labor (1951), "Cotton is a slave crop, nobody is going to pick it that doesn't have to.» Growers informed Congress a few years later that only those with no real choice would hoe sugar beets or harvest tomatoes for twelve hours a day in the desert sun (Congressional Record, 1958: 20). While illegal immigrants were desperate, they were also mobile. Arthur Watkins (1968: 60), chair of the immigration subcommittee in Congress in the 1950s and himself a Utah grower, told an interviewer, "We never picked up any wetbacks if we could avoid it.....My son-in-law says 'They won't stay with you.... They keep moving on, next thing you know, they're gone.'» A western grower speaking to Congress in 1961 (U.S. Congress. House Committee on Agriculture, 1961: 11-13), listed nine advantages of a bracero labor force, the first of which was that the bracero «is not free to leave an employer to seek employment elsewhere." The Bracero Program thus combined the advantages of a desperate and cheap migrant work force with the structure of a government program, providing an element of predictability and stability, and-above all—control, in what was otherwise an unpredictable production process.

Bracero contracts theoretically provided for a number of protections, the specifics of which varied over time. They usually included provisions for braceros to be paid the "prevailing wage," receive a guaranteed amount of work in a given period, and have access to housing and emergency medical care. But, it was common for wages to be set by growers who met at the beginning of the season, determined the wages they were willing to pay, and then informed state officials of 
the "prevailing wage.» Employers sometimes simply ignored contract provisions they found inconvenient, such as housing and food requirements, and guaranteed minimum hours of work (Calavita, 1992).

At its heyday in the mid-1950s, the Bracero Program operated in the following way. Once the U.S. Department of Labor had certified a need for labor, Mexican officials were notified how many workers would be required. Aspiring braceros obtained a permit from municipal Mexican officials, and were then sent to central recruiting centers where there were sometimes ten applicants for each bracero position. After security screening and medical examinations, the selected braceros were dispatched to border reception centers where they signed contracts with employers' representatives. Workers technically had some freedom of choice in this process, ${ }^{1}$ but those who turned down their first offer of employment were often blacklisted by subsequent employers and sent home empty-handed (Anderson, 1963; Galarza, 1964).

A Border Patrol memo from Yuma, Arizona, told of braceros being "fumigated prior to their departure to the United States...by spraying them by use of airplanes, much in the same manner as agricultural fields are sprayed» (U.S. Immigration and Naturalization Service. Border Patrol. "Monthly Sector Activity Report,» Yuma, Arizona, October 1958). Working conditions were often so strenuous and the braceros' hands so "badly scratched" and scarred that efforts to obtain the necessary fingerprints for FBI clearance frequently failed, with the incomplete forms stamped «unclassifiable» and returned to Washington (U.S. Immigration and Naturalization Service. Border Patrol. "Monthly Sector Activity Report,» El Paso, Texas, November 1960).

Lax enforcement of the contract provisions continued to be the norm, in part because INS Commissioner Swing had staked his reputation on reducing the numbers of illegal immigrants and replacing them with braceros-an achievement that would have been impossible had employers determined that the bracero contracts were burdensome. By the end of the 1950s, there was mounting

\footnotetext{
'Some regions and crops were notoriously undesirable. Imperial Valley in California and Yuma, Arizona, offerred among the lowest wages and the most arduous working conditions, with desert temperatures of 110 degrees not uncommon (Anderson, 1963: 28). Other areas and crops were undesirable because of their history of long periods of uncompensated unemployment during the contract period.
} 
evidence of violations of the terms of bracero contracts and revelations of substandard housing and working conditions, as well as repeated charges that the program depressed wages and contributed to unemployment among U.S. farmworkers (Anderson, 1963; Galarza, 1956; Department of Agriculture Report, cited in Congressional Record, 1961: 20257-74; Hadley, 1956: 356).

The moral position of the program's opponents was buttressed in 1960 by the widely acclaimed CBS documentary, "Harvest of Shame," which graphically depicted the poverty and despair of migrant farmworkers in the United States, and precipitated a deluge of mail to the television network and to Congress. At the same time, increasing mechanization of certain crops meant that U.S. growers were less dependent on the bracero system, which by law prohibited using braceros on power-driven machinery. By 1964, the number of braceros was lower than at any time since 1951. Facing increasing attacks from organized labor as well as the liberal administration of President Kennedy, and now confined to the relatively few crops that had eluded mechanization, the controversial Bracero Program was allowed to die in December, 1964.

So poignant a symbol of exploitation did the Bracero Program become and so thorough its discrediting that its political resuscitation has taken several decades. While still controversial in many quarters, some members of Congress have recently responded to pleas from western agricultural interests and put a new bracero-style program back on the political agenda.

Spearheaded by the Western Growers' Association, several farmworker bills have been introduced in Congress in the last two years. Each of these bills would expand or replace the current $\mathrm{H}-2 \mathrm{~A}$ system of temporary workers for agriculture. The H-2A program requires that employers who wish to import workers for seasonal employment advertise first for domestic workers and document a shortage of labor; offer wages that will not «adversely affect» those of local farmworkers; guarantee a certain number of days of work during the contract period; and, provide housing at no cost. Given the ready availability of undocumented workers with no such strings attached, it is perhaps not surprising that few growers apply for workers through the $\mathrm{H}-2 \mathrm{~A}$ program. ${ }^{2}$

${ }^{2}$ In the past few years, $15,000-30,000$ workers have been imported annually under $\mathrm{H}-2 \mathrm{~A}$, constituting only $1-2 \%$ of the agricultural workforce. This number is dwarfed by the undocu- 
Most of the agricultural workers bills that have been introduced in Congress would allow growers to import workers without providing housing; include no guarantees of a minimum number of workdays; allow group piece rates rather than guaranteed minimum wages; and, replace the $\mathrm{H}-2 \mathrm{~A}$ requirement of advertising for domestic workers with a token "work registry" system.

This Bracero Program approach has been endorsed by the Governors of Arizona, New Mexico, Texas (under the governorship of now-President Bush), and Florida, and virtually all agricultural lobbyists. At first glance, this pressure to reestablish a massive foreign labor program makes little sense, given the abundance of undocumented workers available to employers, and high unemployment rates among farmworkers. But, as we have seen, braceros were attractive to growers not as an additional source of labor, but as a particular kind of labor. Specifically, while illegal immigrants had provided a flexible supply of cheap labor, they were also unpredictable, not only because they were subject to deportation but also because they were free agents. And, while agriculture thrives on the flexibility of undocumented workers, at the same time it seeks structure, predictability, and above all, control.

During economic expansions, the inherent tension between the flexibility that undocumented workers provide and their unpredictability is enhanced, as the possibility of alternative employment attracts some migrants away from the fields. So, it is not a shortage of labor that compels growers to seek braceros in this period of expansion, but rather the desire for a workforce that is immune to the laws of supply and demand and is precluded from finding more lucrative employment elsewhere.

Not surprisingly, immigrant advocacy groups and labor unions are fiercely opposed to this effort. Last year, a letter was sent to every member of the House and Senate, signed by 185 organizations, including the AFL-CIO, the UFW, and the Farmworkers' Justice Fund. The letter warned, "The guestworkers would have few rights and would be vulnerable to exploitation" as a captive labor force; "The promise of a green card [would] be a cruel hoax for many workers;" and, the program would add to unemployment and depressed wages among

mented population that is estimated to make up approximately $50 \%$ of the agricultural workforce (GAO, cited in Lewis, July 7, 2000: A4). 
domestic farmworkers (Famrworker Justice Fund, September 11, 2000). Permeating the press releases and "Action Alerts" of these organizations are references to the Bracero Program and the "indentured servitude» such programs create and sanction (Farmworker Justice Fund, 1999).

The contrast between this reaction of organized labor to a new Bracero Program in the U.S. and the response to similar guestworker programs in Spain is striking. The following sections give a brief overview of immigrants in the Spanish economy and the political context of temporary worker programs in Spain, in order to account for this difference.

\section{Immigration and Quota Workers in Spain: A Descriptive Overview}

Since Franco's death, the Spanish economy has grown by spurts and starts, undergoing unprecedented levels of expansion between 1986 and 1990, when over two million new jobs were created, more than in any other European country. And, the economy has continued to grow, adding 1.8 million more new jobs since 1996. While still lagging behind much of western Europe in terms of real wages and standard of living, Spain has also gone far to narrow the gap. Furthermore, Spain's social protections have expanded rapidly and its welfare state is now almost comparable to that of other western European democracies.

The economy in Spain is divided into a technologically advanced primary sector that is highly unionized and regulated, and an extensive underground that contributes an estimated 14\% of Spain's gross domestic product (El Pais, 1998: 55). Spanish employers becry the rigidity of the formal labor market associated with government regulations and collective bargaining. Indeed, they attribute the stubborn double-digit unemployment rate to the red tape that limits their ability to hire and fire workers and dictates employment conditions (Economist, 1996; Elgar, 1993; Maxwell and Spiegel, 1994; El Pais, May 27, 1997: 55).

Since the mid-1980s, Spain has experienced net immigration for the first time in modern history. By 1998 , over 700,000 foreigners had legal residence in Spain, with about half coming from outside the EC, and the vast majority of these non-EC immigrants coming from the third-world. The largest source country is Morocco, with almost twice as many legal immigrants in Spain as any other single country. Most independent sources put the total number of legal 
and illegal immigrants at about one million (Sole, 1995; Colectivo IOE, 1999; El Pais, October 3, 1999: 21).

Most third-world immigrants in Spain work in agriculture, domestic service, tourism, construction, or other low-paying and underground sectors of the economy (Sole, 1995; Izquierdo, 1996; Gonzalez-Anleo, 1993; Pumares, 1996). This immigrant labor is often lauded for the «flexibility» it provides the economy. The former Director-General of Migration has pointed out that a high unemployment rate and the need for immigrant workers are not mutually contradictory, noting that the Spanish labor market "contains certain rigidities" that thirdworld labor helps counteract (quoted in Mercado, 1992: 27).

Indeed, Spanish immigration laws are oriented towards immigration as a labor supply, and contain few provisions for permanent legal residency or naturalization. «Regularization," or legalization, programs are implemented every few years, with applications reaching several hundred thousand (Borras, 1995; Izquierdo, 1996). Even those who are legalized, however, enjoy only temporary legal status and must generally demonstrate continued formal employment and navigate a maze of government bureaucracies to renew their permits. Among the most formidable bureaucratic obstacles to renewing one's legal status is the fact that both a residence permit and a work permit are required, each of which is provided by a different government agency. It is not uncommon that while waiting for one of these permits to materialize, the other expires (de Lucas, 1994: 92). Given the difficulties of retaining legal status, one Spanish immigration scholar has written that the policies result in «institutionalized irregularity» (Santos, 1993: 111).

One of the few ways to migrate legally to Spain is through small quotas that allow workers in temporarily to fill niches in certain sectors. In 1993, a Council of Ministers Agreement in Spain set up a system of national quotas for foreign workers in three sectors: agriculture, unskilled construction work, and domestic service. From a low of 6,000 in 1993 , the number of such quota workers increased to 30,000 in 1994 , reached 60,000 in 1996 , and declined again to 30,000 in 1999 . While the numbers fluctuate from year to year, this quota system for temporary workers remains a cornerstone of Spain's immigration policy.

What is remarkable about the Spanish experience with these guestworker programs is that labor unions and immigrant advocacy groups are their greatest 
supporters. In marked contrast to the political dynamics in the United States, it is labor unions not employers who lobby most vociferously for increases in the number of foreign workers admitted. In discussions prior to the implementation of the 1999 immigration law in Spain, the left-leaning union, CC.OO., insisted that the annual quota for foreign workers was «limited" and should be increased (Escola, 1999: 3). And, the Catalan branch of CC.OO declared in a 1997 policy paper that the «insufficient» quotas should be vastly expanded (Pajares, 1997:11).

Recent scholarship (Watts, 1999; Calavita, 1998) has addressed the immigrant advocacy role that labor unions play in Spain. As Watts (1999) argues, advocacy on behalf of immigrants in part represents enlightened self-interest. According to this argument, with immigration an inevitable by-product of globalization and advanced capitalism, labor leaders reason that it is ultimately more strategic to advocate on behalf of and organize immigrants than to engage in a futile effort to limit immigration and risk alienating a potential constituency. Further, from the point of view of labor it is better to expand the size of the legal immigrant population than to enact restrictive policies that will ipso facto increase the number of illegal immigrants and confine them to the underground economy, out of reach of union rules and protections (Watts, 1999).

Last year, the AFL-CIO reversed its position on immigration, replacing its long-time restrictionism and hostility to undocumented immigrants with a platform that included support for a new legalization program, the repeal of employer sanctions, and a commitment to organizing undocumented workers (Cleeland, 2000: A1). The position of this major U.S. labor union is thus in sync with its Spanish counterpart on most immigration issues, with the exception of guestworker programs. In the remainder of my time, I will argue that it is the distinct historical, legal and political contexts that explain this difference.

\section{The Historical, Legal, and Political Context}

The quota worker system in Spain is technically comparable in a number of ways to the old Bracero Program and to the proposals currently being considered by Congress. In each case, temporary visas are provided to foreign workers to work in a specific industry, to which they are tied for a designated period of time. And, in each case legal status is temporary and precarious, as foreign wor- 
kers in Spain are required to secure another work contract at the end of their initial period of employment in order to retain their legal status.

While there are relatively minor differences in the two contract labor systems-such as the seasonal nature of the U.S. bracero-style programs and their confinement to agriculture-the most dramatic difference is their location in the national political debates of each country. To understand the "progressive" quality of these programs in Spain, it is important to juxtapose them to the larger immigration system. Remember that legal immigrant status in Spain is almost always contingent. That is, even illegal immigrants who are "regularized" in periodic legalization programs must show annually that they have a formal work contract (a daunting task for these populations largely confined to the underground economy), and most legalized immigrants at one time or another fall into illegal status. There is virtually no way to secure permanent legal status or naturalization (outside of marriage to a citizen, and in Spain even this route is fraught with uncertainty [El Periodico, March 19, 1997: 26]). Provisions for permanent legal status have been incorporated in recent laws, but to qualify immigrants must first piece together multiple years of continuous formal work contracts and work and residency permits. These requirements are so unrealistic given the pervasiveness of the underground economy and entail so many bureaucratic hurdles that only a small handful of immigrants have achieved this coveted status.

In this immigration context, the foreign worker program is one of the few routes to legality. Further, the temporary and contingent nature of that legality does not mark quota workers as a particularly vulnerable sub-set of the immigrant population, since this contingency is more or less endemic to the immigrant condition in this legal environment. In this context of «institutionalized irregularity» (Santos, 1993: 111), the legality—albeit temporary-that the quotas provide is welcomed. Indeed, expanding these quotas is one of the most meaningful and realistic avenues to reform available to immigrant advocates. The point is not just that "everything is relativen depending on one's perceptual lens; rather, «everything is relative" to the objective reality in which it is inserted.

If legal immigrant status is more contingent and tenuous in Spain than in the U.S., it is also true that the gap between legal and illegal work is more extreme. I do not mean by this that the informal economy to which undocumented immigrants are confined is any less harsh or precarious in the United States. The 
gap between legal and illegal work is more pronounced in Europe not because the informal economy is worse there, but because the formal economy accords more protections than in the U.S., in large part due to the greater power of organized labor and political parties representing labor.

While labor parties are less powerful in Spain than in many western European countries, and labor unions are generally weaker, nonetheless relative to the United States collective bargaining and government regulations play a key role in the economy. The repercussions of labor's greater power to shape the rules of economic engagement in Spain relative to unions in the more classically liberal American economy, are two-fold. First, it ups the ante on the importance of legal immigrant status, however temporary. While many legal immigrants in Spain find themselves locked in the underground economy despite their legal status, nonetheless legal status is a pre-requisite to a job in the formal economy over which organized labor and government regulations hold substantial sway. And, it is only by expanding the number of immigrants in the formal economy, relative to their numbers in the underground, that organized labor can hope to neutralize the potentially deleterious effect of immigrants on wages and working conditions.

Second, this greater power of organized labor implies a greater ability of labor leaders in Spain to participate in shaping the terms of contracts for quota workers. Unlike the Bracero Program that generally consisted of closed-door bilateral agreements between the Mexican and U.S. governments, and that was often used as a wedge to undermine already weak farmworker unions (Calavita, 1992: 122), in Spain organized labor is more confident of its ability to at least be at the table when the terms of these contracts are hammered out. ${ }^{3}$

Finally, history is important here. While Spanish immigrants at one time performed the role of guestworker in northern Europe, large foreign labor systems are new in this country that has only in the last two decades become a significant immigrant destination. In the United States, instead, the Bracero Program

3 I do not want to exaggerate here. As discussed above, the power of organized labor in Spain has always been weak relative to that of its European neighbors. The point here is that Spanish labor unions exert a greater influence in political-economic affairs than do their counterparts in the U.S. 
casts a long shadow. Having gone down in scandal in the early 1960s, it became synonymous with slave labor and indentured servitude. So strong is this lingering association of a guestworker program with a captive workforce that when then-Senator Pete Wilson (Republican-California) in 1985 introduced the idea of a temporary worker program for agriculture as part of the legislation that later became IRCA, key democrats in the House vowed to kill any bill (and they were true to their word) with such a "de facto slave labor program" attached to it.

\section{The Pleasures and Perils of Cross-Cultural research}

This study of the strikingly different socio-political meanings of foreign worker programs in the U.S. and Spain teaches us both the utility of cross-cultural comparative work, and its risks. On one hand, contrasting the progressive meaning of quota worker programs in Spain with their exploitive connotations in the U.S. can yield important insights about the integral links between immigration policies and the larger economic, cultural and political systems of which they are a part. On the other hand, it is precisely these systemic links with the broader socio-cultural environment that make comparative studies of immigration-or any cross-cultural study for that matter-so fraught with potential for misunderstanding.

Two personal anecdotes could be useful here. The first relates to an experience I had recently when giving a talk in Naples, Italy, on the economic marginalization of immigrants and the spatialization of that marginalization in the form of residential segregation. The speaker who introduced me had not inquired exactly what I was going to talk about; he knew only that I was to speak about immigration in Naples. As I listened intently to his introduction in Italian, I heard him tell the audience that I would be speaking about the problem of the "moschea" in Naples. For a moment I panicked, because I had no idea what "moschea" meant, and I certainly had no intention of talking about it! I soon realized that the audience expected me to address the issue of mosques in this (at least nominally) Catholic society. In short, they were prepared to hear a talk about the increasing multiculturalism that has accompanied immigration to Italy. Indeed, I learned on this brief research trip to Italy that the issue of immigration is overwhelmingly viewed through the lens of multiculturalism. While some scholars and journalists do address the economic (and related social) issues associated with immigration, the question of what it means for Italy to become multi- 
cultural, and as they often say in Italy, "multi-ethnic," is the dominant concern and the major topic of debate. ${ }^{4}$ To talk of immigration then is almost by definition to talk about the "moschea."

This experience not only had unfortunate repercussions for me personallyin that I had to explain why I was not going to talk about what they found most interesting - but it reminded me of the danger in cross-cultural work of assuming that we know the meaning of what we are studying. For, what appear to be similar phenomena (like immigration) or policies (like guestworker programs) may in fact have radically different social meanings and political realities. While this is of course not a new insight-it is in fact a central tenet for ethnographers and anthropologists-taking it seriously means that those of us who engage in cross-cultural work of any kind must always be at least part ethnographer.

Of course, it is not always just social meaning that varies across contexts. In the case of foreign worker programs, we have seen that the implications of these programs vary according to the power of labor, the economic structure, and the immigration systems in which they are inserted. In other words, the larger context in effect determines not just the socio-cultural meaning of these programs, but their economic and social reality as well. And, this brings me to my final point, having to do with the implications of this comparative study for policy.

\section{Policy Implications}

I am often asked by my students whether my critique of immigration restrictionism means that I favor an open border, and if not, what policies I would recommend. It is a difficult question to answer. On one hand, I argue that immigration restrictions are often hypocritical, as immigrants have historically provided and continue to provide, a large contingent of the cheap labor on which the

${ }^{4}$ I do not mean to imply here that Italy is in fact a homogeneous society. An argument can be made that Italy has long included distinct cultural traditions, dramatically different dialects, and other marked dissimilarities often related to geographical regions and social class. What is important here is that in this debate, it is assumed that Italy has been relatively homogeneous, and that immigration is now disrupting that national homogeneity (just as a similar argument is often made about immigration in Spain). 
U.S. economy thrives. And, restrictive immigration policies have the primary effect of further marginalizing the (now illegal) immigrant population, enhancing the "flexibility" they provide employers. On the other hand, an open border not only may be unfeasible, but may jeopardize wages and working conditions in the U.S., as a crowded labor market would further erode labor's already weak bargaining position. For progressives interested in policies that enhance welfare and empower people, the choices appear to be paltry.

Perhaps indicative of our unappealing choices, progressives often stumble into apparent self-contradictions when discussing immigration policy (and I implicate myself here as well). There is, for example, something fundamentally self-contradictory about our tolerance of undocumented immigration, or at least our unwillingness to publically endorse policies aimed at reducing it (sometimes our advocacy on behalf of undocumented immigrants is on the grounds that they fill niches abandoned by U.S. workers and thus have no ill effects on labor), while at the same time opposing guestworker programs on the grounds that they are exploitive of the workers and depress local wages. (I myself have sometimes argued on behalf of undocumented Mexican farmworkers that they are central to California agriculture-which would collapse without their labor-while opposing a new Bracero Program by pointing out that farmworker unemployment in many areas reaches double digits).

What I want to argue here is that this apparent inconsistency (which usually remains unremarked upon and presumably unnoticed) is the consequence of political choices. That is, denouncing undocumented migration would fuel repressive measures antithetical to the kind of empowerment progressives seek. Doomed to failure in this global era of collapsing borders, repressive immigration laws have the sole effect of further criminalizing immigrants. The defense of unauthorized immigrants, and opposition to laws designed to curb undocumented immigration, is thus a political choice. So too is the opposition to a new Bracero Program which, as history has taught us, would enhance the power of agricultural employers while contributing nothing to the lot of immigrants and eroding the power of U.S. labor. In other words, unauthorized immigration and guestworker programs are being evaluated in their political context and on the basis of their political meaning. Seen in this light, the apparent contradiction dissolves, to reveal a consistent political reality. But, if the apparent contradiction in which progressives are caught can be understood once we grasp its poli- 
tical meaning, the nagging question remains: What immigration policy should we endorse?

My comparative analysis of Spanish and U.S. foreign worker programs might help untangle the immigration policy quandary that progressives find themselves in. For, just as this study highlights the importance of political meaning in evaluating public policies, it also reveals the important linkages between immigration policy and broader economic policies and labor relations. Specifically, the impact of a guestworker program depends on the larger context-particularly the labor relations and economic reality-in which it is inserted and of which it is a part.

If immigration policy is one piece of a larger set of economic relations, in the absence of altering these relations, even well-intentioned immigration policies are unlikely to have progressive effects. Indeed, to the extent that their impact is determined by the larger context, immigration policies are likely to reaffirm the relations embedded in that context. It is for this reason that neither extensive undocumented immigration, nor legal worker programs, nor even an open border, can be considered progressive policies, if taken alone. In fact it is predictable that, in the absence of any broader changes in economic relations, each of these policies would further enhance the exploitive nature of those relations.

So when asked to describe an acceptable immigration policy, progressives are at a loss not because their imaginations are limited, or as is sometimes charged, because their analyses are not "policy relevant.» Rather, we are at a loss because immigration policy must be considered as the part of a larger set of economic policies that it is. To do otherwise-to consider it as a discreet realm of policymaking-is to force the choice between the lesser of two evils. No doubt this explains progressives' peculiar tolerance of undocumented immigration, the miseries and marginalities of which are themselves so well documented.

\section{References}

ANDERSON, Henry (1963): Fields of Bondage: The Mexican Contract Labor System in Industrialized Agriculture. Mimeograph. Berkeley, California.

BorRAS, Alegria (1995): Diez Anos de la Ley de Extranjeria: Balance y Perspectivas. Barcelona: Fundacion Paulino Torras Domenech. 
Boudreaux, Richard (2000): "Amid Boom Times for Spain, Aznar in a Fierce Struggle for Reelection", Los Angeles Times, March 12, 2000: A10.

BustamANTE, Jorge (1978): "Commodity-Migrants: Structural Analysis of Mexican Immigration to the U.S." in Stanley Ross (ed.) Views Across the Border. Albuquerque, New Mexico: University of New Mexico Press.

CALAVITA, Kitty (1992): Inside the State: The Bracero Program, Immigration, and the INS. New York: Routledge.

- (1998): «Immigration, Law, and Marginalization in a Global Economy: Notes from Spain", Law and Society Review, Vol. 32, No. 3: 529-566.

CleELlaND, Nancy (2000): "AFL-CIO Calls for Amnesty for Illegal U.S. Workers», Los Angeles Times, February 17, 2000: A1.

COCKCROFT, James D. (1986): Outlaws in the Promised Land: Mexican Immigrant Workers and America's Future. New York: Grove Press.

COLECTIVO IOE (1999): Inmigrantes, Trabajadores, y Ciudadanos: Una Vision de las Migraciones desde Espana. Valencia: Universitat de Valencia.

COMISION INTERMINISTERIAL DE EXTRANJERIA (1998): Anuario Estadistico de Extranjeria. Madrid.

Congressional Record (1958): 85th Congress. 2nd Session.

- (1961): 87th Congress. 1st Session.

CoRneluus, Wayne A. (1992): «From Sojourners to Settlers: The Changing Profile of Mexican Labor Migration to California in the 1980s». Pp. 155-95 in J. Bustamante, R. Hinojosa, and C. Reynolds (eds.), U.S.-Mexico Relations: Labor Market Interdependence. Stanford: Stanford University Press.

Cornelius, Wayne A., Philip L. Martin, and James F. Hollifield (eds.)(1994): Controlling Immigration: A Global Perspective. Stanford: Stanford University Press.

Coutin, Susan Bibler (2000): Legalizing Moves: Salvadoran Immigrants' Struggle for U.S. Residency. Ann Arbor: University of Michigan Press.

DE LUCAS, Javier (1994): Europa? Convivir con la Diferencia? Racismo, Nacionalismo y Derechos de las Minorias. Madrid: Editorial Tecnos.

DJAJIC, Slobodan (1997): «Illegal Immigration and Resource Allocation», International Economic Review, Vol. 38 (\#1): 97-117.

Economist (1996): "A Survey of Spain," 14 December 1996: 3-18. 
ELGAR, Edward (1993) «Spain: Shaping Factors», in A. Jacquemin and D. Wright (eds.), The European Challenges, Post-1992: Shaping Factors, Shaping Actors. Brookfield, VT: E. Elgar Pubs.

El Pais (1997): «La OECD Recomienda a Espana que Siga la Politica de Liberalizacion y Abarate el Despidon, El Pais, May 27, 1997: 55.

- (1998): «La Economia Sumergida Supone 11 Billones, Segun un Estudio,», El Pais, July 9, 1998: 55 .

- (1999) «Espana se Prepara para Duplicar su Inmigracion en los Tres Anos», El Pais, October 3, 1999: 21.

El Periodico (1997): «Boda 'Ilegal' para Denunciar los Obstaculos a los Matrimonios Interetnicos", El Periodico, March 19, 1997: 26.

EsCOLA, Carles (1999): «CC.OO. Advierte de que la Nueva Ley Discriminara Laboralmente a los Inmigrantes", El Pais Digital, August 5, 1999: 3.

FARMWORKER JUSTICE FUND (2000): «Action Alert,» August, 2000.

- (1999): "Guestworker Legislative Update and Alert,» May 26, 1999.

FishMAN, Robert M. (1990): Working-Class Organization and the Return to Democracy in Spain. Ithaca: Cornell University Press.

GalARZA, Ernesto (1964): Merchants of Labor: The Mexican Bracero Story. Sage Yearbook in Politics and Public Policy. Santa barbara, California: McNally and Loftin, Publishers.

GonZAlEZ-ANLEO, J. (1993): «El Poblado Marroqui de Manuel Garrido: Una Aproximacion Sociologica", Sociedad y Utopia, Vol. 1: 171-92.

GunTHER, Richard, Giacomo SANI, and Goldie Shabad (1986): Spain After Franco: The Making of a Competitive Party System. Berkeley: University of California Press.

HadLey, Eleanor (1956): "A Critical Analysis of the Wetback Problem», Law and Contemporary Problems, Volume 21: 334-57.

Halsell, Grace (1978): The Illegals. New York: Stein and Day.

HamanN, Kerstin (1998): "The Pacted Transition to Democracy and Labour Politics in Spain", South European Society and Politics, Volume $2(\# 2)$.

IZQUIERDO, Antonio (1996): La Inmigracion Inesperada. Madrid: Editorial Trotta.

- (1999): «Inmigracion y Estado de Bienestar: Temporales o Definitivos», El Pais, February 7, 1999: 17. 
KIRSTEIn, Peter Neil (1973): Anglo Over Bracero: A History of the Mexican Workers in the United States from Roosevelt to Nixon. PhD. dissertation, Saint Loius University.

LEWIS, Finlay (2000): “Employers Pressing to Import Workers», The San Diego UnionTribune, July 7, 2000: A3-A4.

MARKovits, ANDraei and Samantha KazARInov (1978): "Class Conflict, Capitalism, and Social Democracy: The Case of Migrant Workers in the Federal Republic of Germany", Comparative Politics, Volume 10, No. 2: 373-391.

MATE GARCIA, Jorge (1994): Demanda, Oferta y Ajustes Salariales en el Mercado de Trabajo Espanol. Valladolid: Secretariado de Publicaciones, Univ. de Valladolid.

MaXwell, Kenneth and STEVen SPIEgel (1994): The New Spain: From Isolation to Influence. New York: Council on Foreign Relations Press.

Mercado (1992): «Miedo a lo Desconocido,» 24 February 1992: 27.

MOORE, Truman (1965): The Slaves We Rent. New York: Random House.

NaVARro, Vicenc (1997): “Un Nuevo Dogma en Espana,» El Pais, May 5, 1997: 13-14.

Newsweek (2000): '"Spain Has Changed.' An Interview with Prime Minister Jose Maria Aznar. April 10, 2000: 24.

PAJARES, Miguel (1997): «La Inmigracion Extranjera en Catalunya y Los Retos que Plantea", Anuari del Centre d'informacio per a Treballadors Estrangers-Catalunya.

Pfeffer, Max J. (1980): «The Labor Process and Corporate Agriculture: Mexican Workers in California». The Insurgent Sociologist, vol. 10 (\#2): 25-44.

President's COMMISSION ON MigRATORY LABOR (1951): Migratory Labor in American Agriculture. Report of the President's Commission on Migratory Labor. Washington, DC: U.S. Government Printing Office.

Pumares, Pablo (1996): La Integracion de los Inmigrantes Marroquies: Familias Marroquies en la Comunidad de Madrid. Barcelona: Fundacion 'La Caixa.'

REINAN, John (1999): «Farmers Back Illegal Immigrant Bill», The Tampa Tribune, June $22,1999$.

RichaRDS, Andrew J. (1999): “Spain: From Isolation to Integration». Pp 161-196 in R. Tiersky (ed.), Europe Today: National Politics, European Integration, and European Security. Lanham: Rowman and Littlefield Publishers, Inc.

SANTOS, Lidia (1993): «Elementos Juridicos de la Integrwacion de los Extranjeros». In G. Tapinos (ed.) Inmigracion e Integracion en Europa. Barcelona: Itiera Libros. 
Sole, Carlota (1995): Discriminacion Racial en el Mercado de Trabajo. Madrid: Consejo Economico y Social.

U.S. Congress. House Committee on Agriculture (1947): «Farm Labor Supply Program». Hearings before the House Committee on Agriculture. 80th Congress. 1 st Session.

- (1961): «Extension of Mexican Farm Labor Program». Hearings before the Subcommittee on Equipment, Supplies, and Manpower. 87th Congress. 1st Session.

U.S. IMMigRation and Naturalization SeRVICE (1954): "Report to the American Section of the Joint Commission on Mexican Migrant Laborm, unpublished report. INS Archives, accession \#67A3254, Box 8.

U.S. Immigration and Naturalization Service. Border PaTrol (1958): «Monthly Sector Activity Report", Yuma, Arizona, October, 1958.

- (1960): «Monthly Sector Activity Report», El Paso, Texas, November 1960.

WATKINS, Arthur (1968): Oral History Interview with Senator Arthur Watkins. Eisenhower Administration Project. Columbia University Library.

WATTS, Julie (1999): «Italian and Spanish Labour Leaders' Unconventional Immigration Policy Preferences", South European Society and Politics, Vol. 3. 